\title{
What is the rationale for early intervention after osteoporotic fractures to avoid recurrent fractures?
}

Tekrarlayan kırıkları önlemek için osteoporotik kırıklardan sonra erken girişimin gerekçesi nedir?

\author{
O. Şahap Atik, MD. \\ Department of Orthopedics and Traumatology, Medical Faculty of Gazi University, Ankara, Turkey
}

The increase in the proportion of elderly people in population is contributing to a greater proportion of people with osteoporotic fractures and a higher cost for osteoporosis. The awareness and knowledge on osteoporosis and osteoporotic fractures have increased in the last decade. However, the problem of a subsequent hip fracture has not been emphasized enough. ${ }^{[1,2]}$

This is also true for a wrist fracture which is a predictor of subsequent fractures, both vertebral and nonvertebral. There may be substantial missed opportunities for intervention in the large number of females who present with wrist fractures. ${ }^{[3]}$

The risk of a subsequent fracture immediately after an osteoporotic fracture is highest immediately after the event. ${ }^{[4]}$ This is the rationale for early intervention after osteoporotic fractures to avoid recurrent fractures, and the treatment options available for patients at high risk of subsequent fractures may contribute to clinical decisionmaking and improved outcomes for patients with

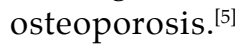

\section{REFERENCES}

1. Moradi R, Atik OS. Are orthopedic surgeons more aware of medical treatment of osteoporotic fractures in the last decade?. [Article in Turkish] Eklem Hastalik Cerrahisi 2014;25:80-4.

2. Atik OS. Second hip fracture in elderly patients. Eklem Hastalik Cerrahisi 2014;25:125.

3. Crandall CJ, Hovey KM, Cauley JA, Andrews CA, Curtis JR, Wactawski-Wende J, et al. Wrist Fracture and Risk of Subsequent Fracture: Findings from the Women's Health Initiative Study. J Bone Miner Res 2015;30:2086-95.

4. Johnell O, Kanis JA, Odén A, Sernbo I, Redlund-Johnell I, Petterson C, et al. Fracture risk following an osteoporotic fracture. Osteoporos Int 2004;15:175-9.

5. Ganda K, Puech M, Chen JS, Speerin R, Bleasel J, Center $\mathrm{JR}$, et al. Models of care for the secondary prevention of osteoporotic fractures: a systematic review and metaanalysis. Osteoporos Int 2013;24:393-406.

\footnotetext{
- Correspondence: O. Şahap Atik, MD. Gazi Üniversitesi Tıp Fakültesi Ortopedi ve Travmatoloji Anabilim Dalı, 06500 Beşevler, Ankara, Turkey. Tel: +90 312 - 2025528 Fax: +90 312 - 2129008 e-mail: satikmd@gmail.com
} 